\title{
Bioremoval of Chromium, Copper and Cadmium by Bacillus cereus in Simulated Electroplating Wastewater
}

\author{
Yulinah Trihadiningrum ${ }^{1}$, Tutut Arinda ${ }^{1}$, Umi Sholikah ${ }^{1}$, Maya Shovitri ${ }^{2}$, Susi Agustina Wilujeng ${ }^{1}$, \\ and Ellina S. Pandebesie ${ }^{1}$
}

\begin{abstract}
Heavy metal pollution is one of environmental problems, which is caused by the discharge of improperly treated industrial wastewater. Electroplating industry generates wastewater containing heavy metals, which include chromium, copper and cadmium. Biological treatment using bacteria has been considered as a new alternative for treatment of heavy metal containing wastewater. The bacteria play an important role in the bioremediation of heavy metal contaminated environment. Bacillus cereus was known as cosmopolitan bacteria with high resistance to pollutants. This study was conducted to measure the viability of two strains of Bacillus cereus in chromium, copper and zinc containing cultures, and the bioremoval efficiencies of the heavy metals.. The bioremoval efficiencies were measured using spectrophotometric method. The bacterial viability was measured according to the Optical Density of the culture. The results showed that both B. cereus strains were viable in culture containing chromium, copper, and cadmium with different concentrations. The highest tolerance of the bacteria was observed in chromium containing culture, where highest chromium bioremoval efficiency of $51.8 \%$ was performed by ATCC 9632 strain at chromium concentration of $102.4 \mathrm{mg} / \mathrm{L}$, in varied concentration range up to $360 \mathrm{mg} / \mathrm{L}$. Whereas the highest copper bioremoval efficiency of $100 \%$ was achieved in the cultures of B. cereus ATCC 1178 and ATCC 9632 at copper concentration of $2 \mathrm{mg} / \mathrm{L}$ in tested concentration range up to $10 \mathrm{mg} / \mathrm{L}$. The highest cadmium bioremoval efficiency of $77 \%$ was achieved by ATCC 9632 strain at concentration of $15 \mathrm{mg} / \mathrm{L}$ in concentration range up to $25 \mathrm{mg} / \mathrm{L}$.
\end{abstract}

Keywords-Bacillus cereus, bioremoval, electroplating wastewater.

\section{INTRODUCTION}

I dustrial activities have been blamed to cause heavy metal pollution due to the discharge of improperly treated wastewater [1]. Heavy metal is one of the most concerned environmental issues because of its toxicity, although some elements are known to have important biological functions [2]. When industrial wastewater is discharged without being processed, the heavy metals may threaten water resource quality, and contribute damaging effect to human life and the environment [3].

The toxicological effects of heavy metals on biological processes are very complex and depended on the species of organisms, the solubility and concentration of the metals, and the wastewater characteristics, such as $\mathrm{pH}$, presence and concentration of cations or other molecules, and suspended solids. Risk and toxicity level of industrial wastes are highly dependent on the interaction of the components, which exist in the waste. [4]. At high concentrations, heavy metals can cause disorders in humans, fauna, flora, and microorganisms. Heavy metal toxicity caused by disturbance in the conformational structure of nucleic acids, proteins, or disruption of oxidative phosphorylation and osmotic balance [5].

Electroplating industry is one of the industries that produce wastewater containing heavy metals in large quantities, which includes chromium, copper and cadmium [6]. Generally, heavy metal concentrations in electroplating wastewater exceed the quality standards [7]. Chromium has two oxidation states, namely trivalent and hexavalent ions. Hexavalent chromium is more toxic

${ }^{1}$ Yulinah Trihadiningrum, Tutut Arinda, Umi Sholikah, Agustina Wilujeng, and Ellina S. Pandebesie are with Department of Environmental Engineering, Faculty of Civil Engineering and Planning, Institut Teknologi Sepuluh Nopember, Surabaya, 60111, Indonesia. E-mail: yulinah_t@enviro.its.ac.id.

${ }^{2}$ Maya Shovitri is with Department of Biology, Faculty of Mathematics and Science, Institut Teknologi Sepuluh Nopember, Surabaya, 60111, Indonesia. than the trivalent because of its high solubility and strong ability as oxidizing agent. Chromium can react with nucleic acid and other cell components to produce mutagenic and carcinogenic effects on biological system [8]. Copper is an essential trace element for plants and animals. Some materials are toxic if ingested or inhaled [9]. Cadmium concentrations in some industrial waste are in the range of $0.1-100 \mathrm{mg} / \mathrm{L}$ [10]. According to the industrial wastewater quality standards of East Java Governor Decree No. 45 2002, the maximum chromium, copper and cadmium concentration are $0.5 \mathrm{mg} / \mathrm{L}, 1 \mathrm{mg} / \mathrm{L}$ and $0.05 \mathrm{mg} / \mathrm{L}$ respectively.

Microorganisms are considered as the best indicator of environmental condition changes. Although initially very sensitive to the presence of metal in the environment, the microorganisms will quickly adapt to the specific environmental conditions. Several microbial taxa, such as Pseudomonas, Bacillus, Aspergillus, Phanerochaete, Serratia, and Enterobacter have been identified to have the capability of removing chromium, copper, cadmium, nickel, and cobalt [11][12].

The most resistant bacteria to heavy metals is Bacillus. Bacillus is a gram positive, rod shaped, aerobic and spore-forming bacteria. Gram positive bacteria have higher ability to bind metals than the gram-negative due to the structure of their cell walls. The cell wall structure of gram-positive bacteria consists of teichoic acids, and other acids associated with the cell wall. Additionally, the presence of phosphate and carboxyl groups plays an important role in metal binding [13].

Bacteria can be used to remove heavy metals from the environment. Heavy metal bioremoval mechanism involves biosorption and bioaccumulation. Biosorption can be performed by living and dead cells, which is based on several mechanisms such as complexation, ion exchange, adsorption, chelation and precipitation. Bioaccumulation mechanisms can occur in living cells 
only through intracellular sequestration followed by localization of metal [14] [15].

The objectives of this research were to measure the viability of Bacillus cereus in simulated electroplating wastewater and the bioremoval efficiency of the heavy metals.

\section{METHOD}

Two strains of bacteria were used in this research. These bacteria were B. cereus ATCC 1178 and B. cereus ATCC 9632, of which cultures were obtained from Laboratorium Balai Kesehatan Yogyakarta, Indonesia. Potassium dichromate, copper (II) chloride, and cadmium chloride solutions were used as chromium, copper and cadmium sources. Simulated wastewater was prepared by adding chromium, copper and cadmium source solutions to Nutrient Broth (Oxoid) medium. The experiment was conducted in $250 \mathrm{~mL}$ batch reactors. This research was started with electroplating wastewater characterization and Range Finding Test measurements in order to determine heavy metal concentration range to be used in this research. Range Finding Test was done using streak plate method. The Range Finding Test was conducted by growing the bacteria in selective Nutrient Agar (NA) medium containing various chromium (VI), copper and cadmium concentrations. This test was observed until no bacterial growth occurred. Bacterial isolates were inoculated aseptically in the medium, and incubated for 24 hours at $37^{\circ} \mathrm{C}$. The colony growth was compared with that of control.

Bacterial viability was measured at highest metal concentration ranges based on the result of Range Finding Test, where growth was still able to be measured. Bacterial strain isolates were inoculated into the media at selected metal concentrations, and shaked at $130 \mathrm{rpm}$ at room temperature. Bacterial viability was measured according to optical density (OD) at $600 \mathrm{~nm}$. The OD levels were measured every 6 hours.

Heavy metal concentrations in bacterial cultures were measured twice, before and after $72 \mathrm{hr}$ treatment for determining bioremoval efficiencies. Chromium concentration was measured by diphenylcarbazide method. Copper and cadmium concentrations were measured using atomic absorption spectrophotometry [16]. Heavy metal bioremoval efficiency was calculated from the difference between the initial concentration of the metal in the medium to a final concentration of metal after 72 hour treatment

\section{RESULT AND DISCUSSION}

\section{A. Bacterial Viability}

1) Bacterial Viability in Chromium Containing Medium

The bacterial viability was determined in cultures with maximum metal concentrations, where the bacterial growth was still measurable.

Both strains of $B$. cereus showed measurable growth at copper concentrations up to $369 \mathrm{mg} / \mathrm{L}$. The viability of B. cereus ATCC 1178 decreased with the increase of copper concentrations (Fig 1a). Similar phenomenon was shown by B. cereus ATCC 9632 (Fig 1b), with slight indication of stronger resistance of ATCC 1178 strain to copper than that of ATCC 9632. This result proved that chromium has negative effect on $B$. cereus growth.

The lower cell viability in higher concentrations of chromium showed relevant results to chromium bioremoval efficiency as described earlier. The increase of chromium concentrations ceased bacterial growth due to toxic effects of metals [17].

Similar finding was reported by Srinath et al. [17] in bioaccumulation study of chromate resistant bacteria. The toxic and mutagenic effects of chromium affected the bacterial growth. These toxic effects were attributed to alteration of genetic material and physiological and metabolic reactions.

\section{2) Bacterial Viability in Copper Containing Medium}

The viabilities of B. cereus ATCC 1178 in cultures containing copper at concentrations below $10 \mathrm{mg} / \mathrm{L}$ were slightly higher than that in control culture (Fig. 2a). These data convinced the fact that copper is a micronutrient, which supports bacterial metabolism at low concentrations [18]. Copper addition to B. cereus ATCC 9632 culture showed comparable effects to that of control culture (Fig. 2b). This meant that ATCC 1178 strain is slightly more tolerant to copper than ATCC 9632 strain. Copper is a component of metalloenzymes and proteins, and becomes a part of the prosthetic group that contributes to oxidation and reduction processes in metabolism [19].

3) Bacterial Viability in Cadmium Containing Medium

Both strains of $B$. cereus were viable in cadmium concentration range up to $25 \mathrm{mg} / \mathrm{L}$. The viabilities of the two strains were worse than those in control cultures (Fig. 3a and b). Cadmium is known as one of the most powerful biological inhibitors, even at low concentrations [20]. Bacteria have the ability of resistance to heavy metals because it has heavy metals resistant gene. Heavy metals resistant genes found in plasmids, transposons and bacterial chromosome. These genes encode the structural and enzymatic proteins that function in the process of bioaccumulation and biosorption of metal. Resistance to chromium metal is encoded in the $\mathrm{Chr}$ operon, copper metal resistance encoded in the Cop operon, whereas cadmium metal resistance encoded in czcD operon [21][22].

B. Bioremoval efficiency

1) Chromium bioremoval efficiency

Chromium bioremoval efficiencies by B. cereus ATCC 1178 were $47.4 \%, 24.9 \%$ and $13.9 \%$ at 102.4 $\mathrm{mg} / \mathrm{L}, 241.4 \mathrm{mg} / \mathrm{L}$, and $369.4 \mathrm{mg} / \mathrm{L}$ concentrations respectively. Those by B.cereus ATCC 9632 was slightly higher than the ATCC 1178 strain.

$51.8 \%, 25.3 \%$ and $19.9 \%$ as shown at Fig. 4. Both bacterial strains showed comparable capabilities in removing this metal. When metal concentrations increased, the bioremoval efficiency lowered. Chromium bioremoval efficiency by B. cereus ATCC 9632 was slightly higher than the ATCC 1178 strain.

The difference in chromium bioremoval efficiencies of the two Bacillus strains might be caused by the difference in resistance mechanism of each bacterial strain. This mechanism occurs through multiple mechanisms, which include metal exclusion by permeability barrier, active transport to out of the cell, intracellular metal adsorption by metal binding proteins, extracellular adsorption, enzymatic detoxification of metals into forms that are less toxic and reduced 
sensitivity of cellular targets of metal. Each bacterial strain has a specific mechanism to adapt with metal existence in their growth medium [3].

\section{2) Copper Bioremoval Efficiency}

The bioremoval efficiency of copper by B. cereus ATCC 1178 were $100 \%, 79.5 \%$ and $66.1 \%$ in copper concentrations of $2 \mathrm{mg} / \mathrm{L}, 6 \mathrm{mg} / \mathrm{L}$, and $10 \mathrm{mg} / \mathrm{L}$ respectively (Fig. 5). Those of the ATCC 9632 strain were $100 \%, 49.5 \%$ and $56.3 \%$ at similar copper concentrations. The bacterial strain ATCC 1178 showed higher copper bioremoval efficiencies than that of ATCC 9632. This is different from the results of chromium bioremoval, where B. cereus ATCC 9632 has higher bioremoval efficiency than the other one. Both strains of B. cereus showed bioremoval efficiency of $100 \%$ at $2 \mathrm{mg} / \mathrm{L}$ copper concentration.

\section{3) Cadmium Bioremoval Efficiency}

The bioremoval efficiency of cadmium by B. cereus ATCC 1178 and B. cereus ATCC 9632 are shown at Fig. 6. Bioremoval efficiencies at $10 \mathrm{mg} / \mathrm{L}$ and $15 \mathrm{mg} / \mathrm{L}$ cadmium concentrations was higher than those at 25 $\mathrm{mg} / \mathrm{L}$ concentration, whereas that of ATCC 9632 strain in $15 \mathrm{mg} / \mathrm{L}$ concentration was highest.

Cadmium toxicity is caused by interaction between cadmium and prosthetic group of enzymes. This interaction will disturb enzymes activity [23]. When compared, B. cereus ATCC 9632 showed higher cadmium bioremoval efficiency than the other strain.

\section{CONCLUSION}

This paper suggests that $\mathrm{B}$. cereus is most tolerant to chromium, when compared to copper and cadmium. The highest chromium bioremoval efficiency of $51.8 \%$ was performed by B. cereus ATCC 9632 at chromium concentration of $102.4 \mathrm{mg} / \mathrm{L}$. Whereas the highest copper bioremoval efficiency of $100 \%$ was observed in B. cereus ATCC 1178 and B. cereus ATCC 9632 cultures at copper concentration of $2 \mathrm{mg} / \mathrm{L}$. The highest cadmium bioremoval efficiency of $77 \%$ was achieved by B. cereus ATCC 9632 at cadmium concentration of 15 $\mathrm{mg} / \mathrm{L}$.

\section{AKNOWLEDGEMENT}

The authors gratefully acknowledge the Center for Research and Public Service of ITS for awarding Hibah Pendukung Unggulan BOPTN 2013, which supported the implementation of this research.

\section{REFERENCES}

[1] V. R. Tirado, C. G. Ruiz, B. G. Gilc, "Cu and Pb biosorption on Bacillus thioparans strain U3 in aqueous solution: Kinetic and equilibrium studies ", Chemical Engineering Journal, vol. 181, pp. $352-359.2012$.

[2] M. Abbas, Parveen, Z. Iqbal, M. Riazuddin, S. Iqbal, M. Ahmed, R. Bhutto, "Monitoring of toxic metals (cadmium, lead, arsenic and mercury) in vegetables of Sindh, Pakistan. Kathmandu University Journal of Science", Engineering and Technology, vol. 6, pp. 60-65. 2010.

[3] R. Singh, A. Kumar, A. Kirrolia, R. Kumar, R. Yadav, N. Bishnoi, R. Lohchab, "Removal of sulphate, COD and Cr(VI) in simulated and real wastewater by sulphate reducing bacteria enrichment in small bioreactor and FTIR study", Bioresource Technology vol. 102,pp. 677-682. 2011.

[4] F. Fu, Q. Wang, "Removal of heavy metal ions from waste waters: A review". Journal of Environmental Management vol. 92, pp. 407-418. 2011.
[5] M.C.V. García, M.J. López, F.S. Estrella, J. Moreno, “Compost as a source of microbial isolates for the bioremediation of heavy metals: In vitro selection". Science of the Total Environment, vol. 431, pp. 62-67. 2012.

[6] T. Fukuta, H. Matsuda, F. Seto, K. Yagishita, "Sulfuration treatment of electroplating wastewater for selective recovery of copper, zinc and nickel resource", Global NEST Journal vol. 2, pp. 131-136. 2006

[7] K. Sumada, "Kajian Instalasi Pengolahan Air Limbah Industri Elektroplating yang Efisien", Jurnal Teknik Kimia vol 1, pp. 1-8. 2006.

[8] G. Cheng, X. Li. "Bioreduction of Chromium (VI) by Bacillus sp. isolated from soils Of iron mineral area European Journal of Soil Biology", vo. 45, pp. 483-487. 2009.

[9] R. Andreazza, S. Pieniz, L. Wolf, M. KuoLee, F. Camargo, B Okeke, "Characterization of copper bioreduction and biosorption by a highly copper resistant bacterium isolated from coppercontaminated vineyard soil", Science of the Total Environment, vol. 408, pp. 1501-1507. 2010.

[10] D. L Vullo, H. M. Ceretti, M. A. Daniel, S.A.M. Ramizez, A Zalts, "Cadmium, zinc and copper biosorption mediated by Pseudomonas veronii 2E". Bioresource Technology, vol. 99, pp. 574-558. 2008.

[11] K. Kannan, R. Krishnamoorthy, “ Isolation of mercury resistan bacteria and influence of abiotic factors on bioavailability of mercury - A case study in Pulicat Lake North of Chennai, South East India". Science of the Total Environment vol. 367, pp. 341353. 2006.

[12] S. Congeevaram, S. Dhanarani, J. Park, M. Dexilin, K Thamaraiselvi, "Biosorption of Chromium and nickel by heavy metal resistant fungal and bacterial isolates". Journal of Hazardous Material, vol. 146, pp. 270-277. 2007.

[13] F. Colak, N. Atar, D. Yazicioglou, A. Olgun, "Biosorption of lead from aqueous solutions by Bacillus strains possessing heavy metal resistance", Chemical Engineering Journal, vol. 173, pp. 422-428. 2011

[14] S.S. Ahluwalia, D. Goyal, "Microbial and plant derived biomass for removal of heavy metals from wastewater". Bioresource. Technology, vol. 12, pp. 2243-2257. 2006.

[15] R. Kumar, D. Bhatia, R. Singh, N. Bishnoi, "Metal tolerance and sequestration of $\mathrm{Ni}(\mathrm{II}), \mathrm{Zn}(\mathrm{II})$ and $\mathrm{Cr}(\mathrm{VI})$ ions from simulated and electroplating wastewater in batch process: Kinetics and equilibrium study". International Biodeterioration \& Biodegradation, vol. 66, pp. 82-90. 2012.

[16] L. Clesceri, E. Arnold, E. Greenberg, A.D. Eaton, " Standard Methods for Examination of Water and Wastewater", 20 ed. American Public Health Association, American Water Work Association, Water Environment Federation. 1999.

[17] T. Srinath, T. Verma, V.W. Rameteke, S.K. Gark, "Chromium (VI) biosorption and bioaccumulation by chromate resistant bacteria. Chemosphere", vol. 48, pp. 427-435. 2002.

[18] R. Andreazza, S. Pieniz, L. Wolf, M. KuoLee, F. Camargo, B Okeke, "Characterization of copper bioreduction and biosorption by a highly copper resistant bacterium isolated from coppercontaminated vineyard soil", Science of the Total Environment, vol. 408, pp. 1501-1507. 2010.

[19] P. Anand, J. Isar, S. Saran, R. K. Saxena, "Bioaccumulation of copper by Trichoderma viride", Bioresource Technology, vol. 97 pp. 1018-1025. 2006

[20] A. Hynninen, "Zinc, cadmium and lead resistance mechanisms in acteria and their contribution to biosensing". Academic Dissertation in Microbiology. University of Helsinki. 2010.

[21] R.A.I Shanab, A.P. Berkum, J.S. Angle, "Heavy metal resistance and genotypic analysis of metal resistance genes in gram-positive and gram-negative bacteria present in $\mathrm{Ni}$-rich serpentine soil and in the rhizosphere of Alyssum murale", Chemosphere, vol. 68 pp. 360-367. 2007.

[22] D. Iglesia, V. Heredia, J.P. Pavissich, S. Freyhoffer,S., Andrade, S., J.A Correa, B. Gonzalez, “ Novel polymerase chain reaction primers for the specific detection of bacterial copper P-type ATPases gene sequences in environmental isolates and metagenomic DNA", Letters in Applied Microbiology, vol.50 pp. 552-562. 2010.

[23] H. Palar, " Pencemaran dan Toksikologi Logam Berat", Jakarta Rineka Cipta, 1994. 


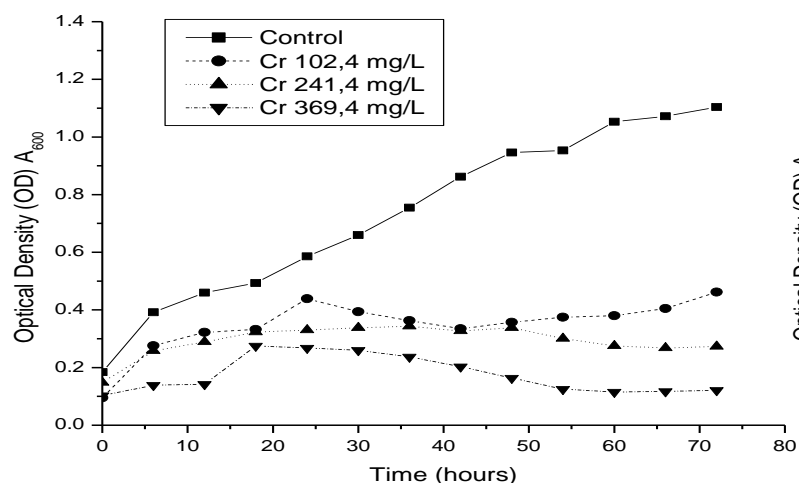

(a)

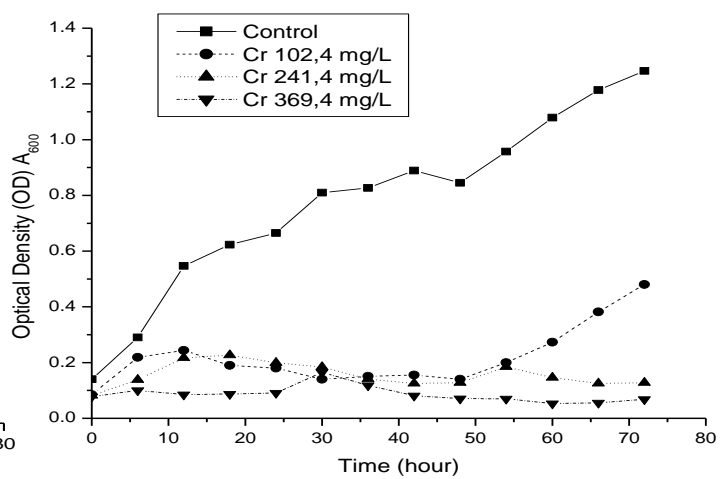

(b)

Figure 1. Bacterial viability in chromium containing culture media. (a) B. cereus ATCC 1178 (b) B. cereus ATCC 9632

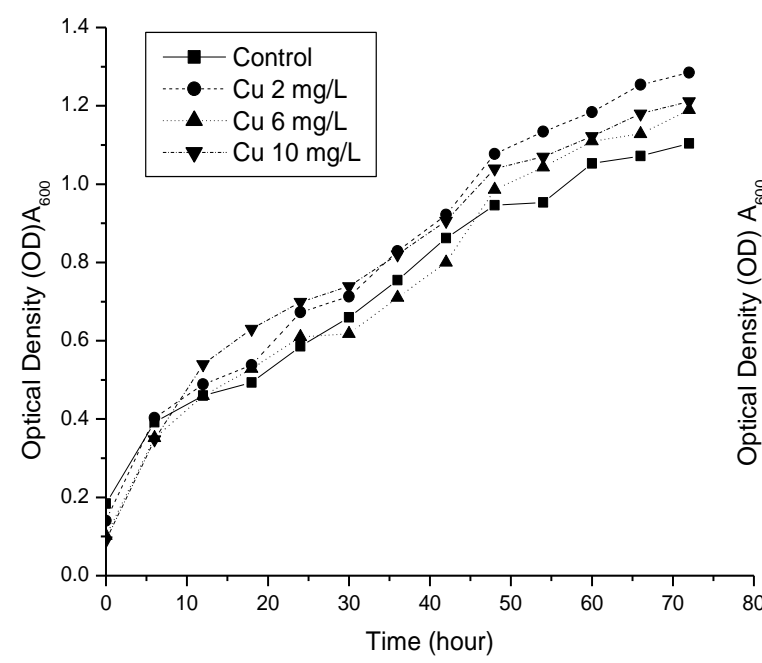

(a)

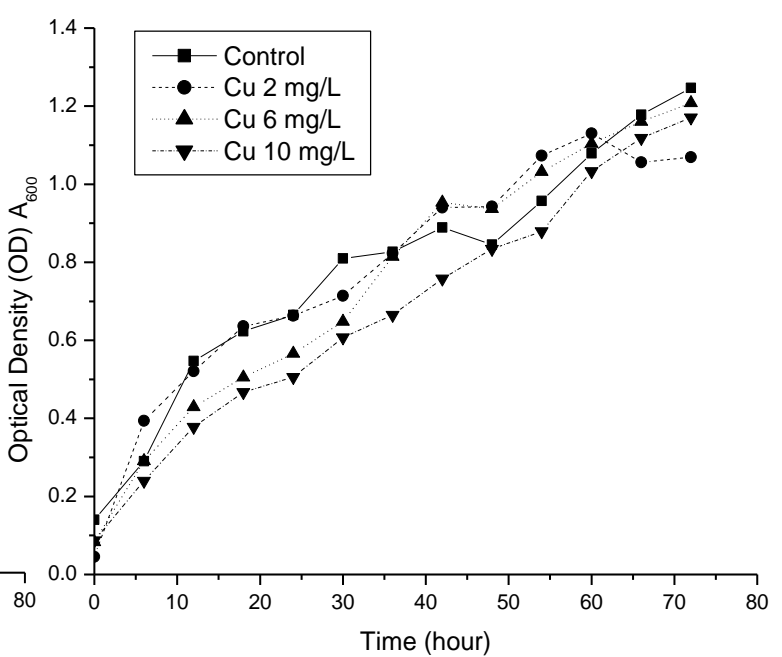

(b)

Figure 2. Bacterial viability in copper containing medium. (a) B. cereus ATCC 1178 (b) B. cereus ATCC 9632

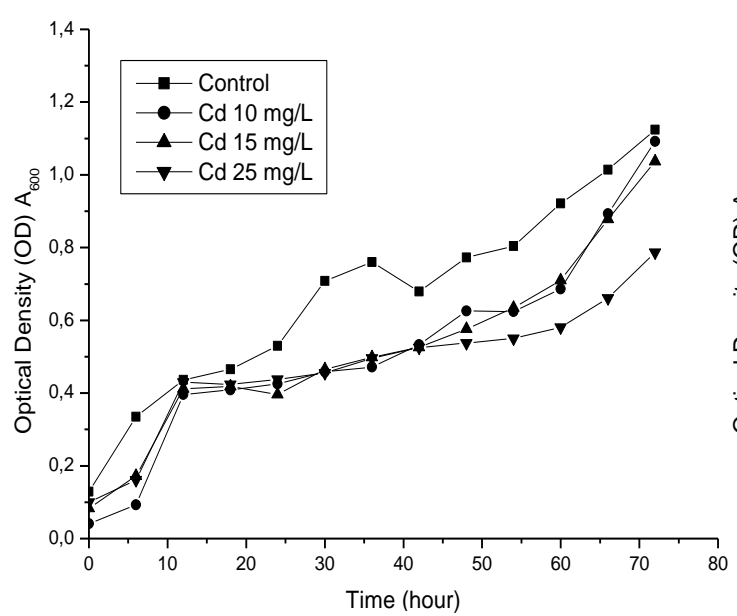

(a)

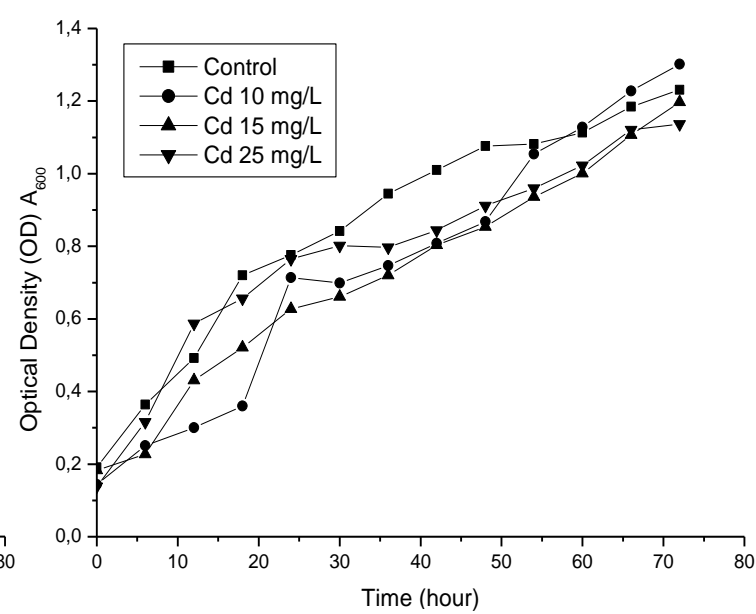

(b)

Figure 3. Bacterial viability in copper containing cultures of (a) B. cereus ATCC 1178 (b) B. cereus ATCC 9632 


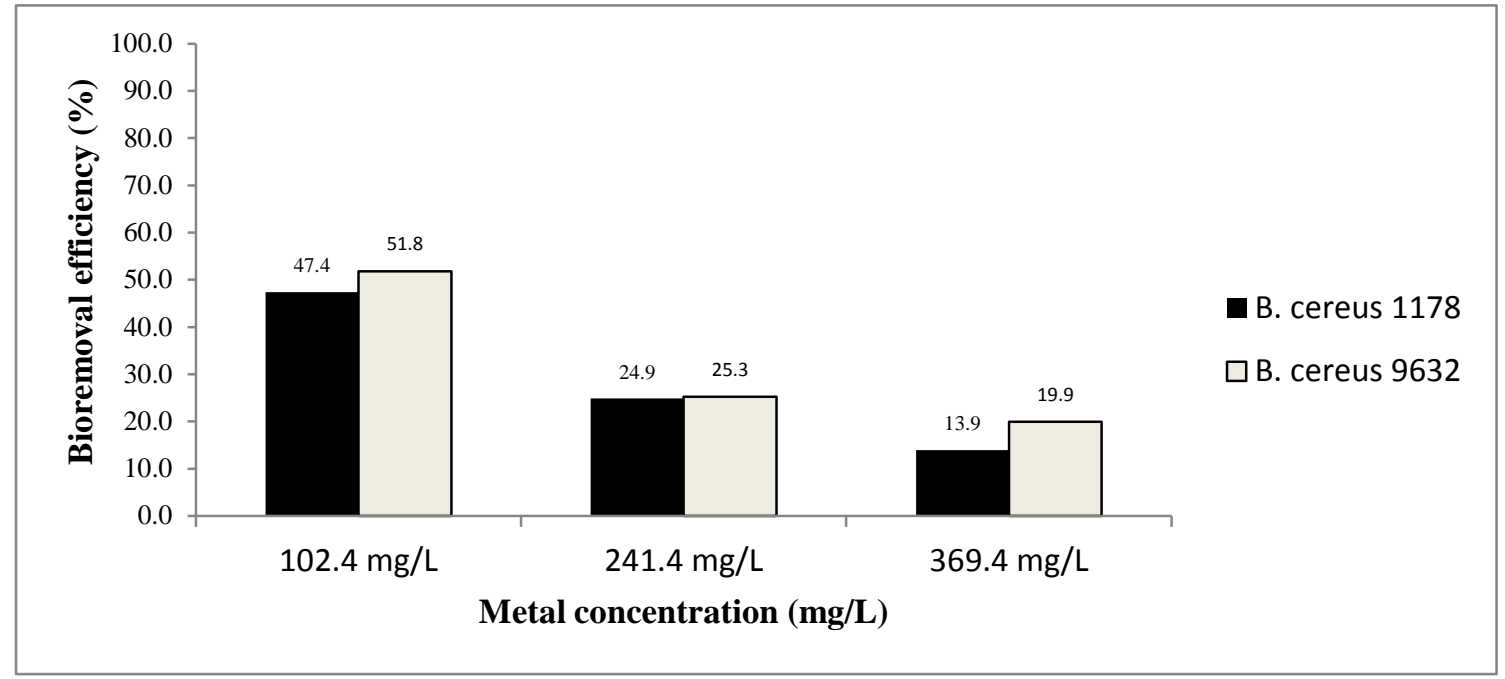

Figure 4. Bioremoval efficiency of chromium by B. cereus ATCC 1178 and B. cereus ATCC 9632

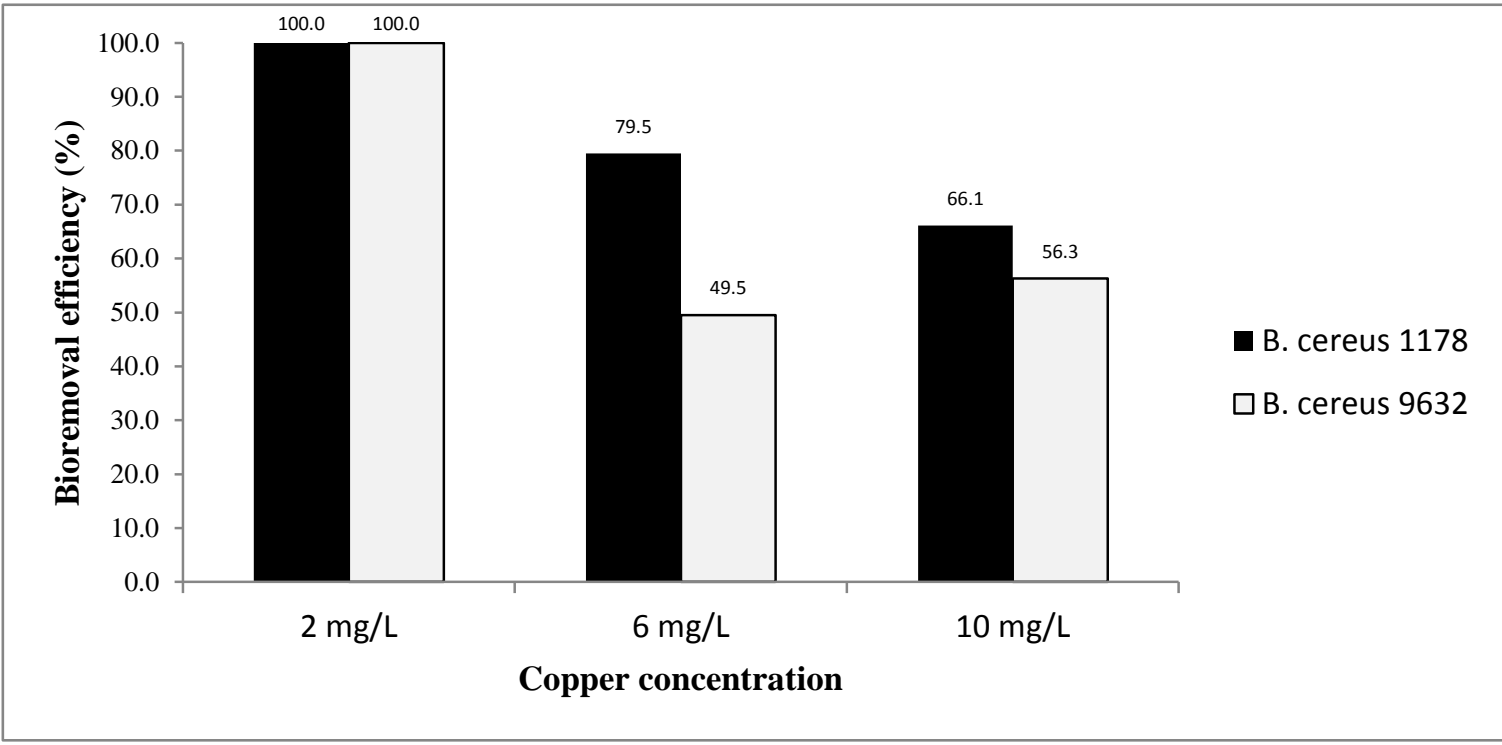

Figure 5. Bioremoval efficiency of copper by B. cereus ATCC 1178 and B. cereus ATCC 9632

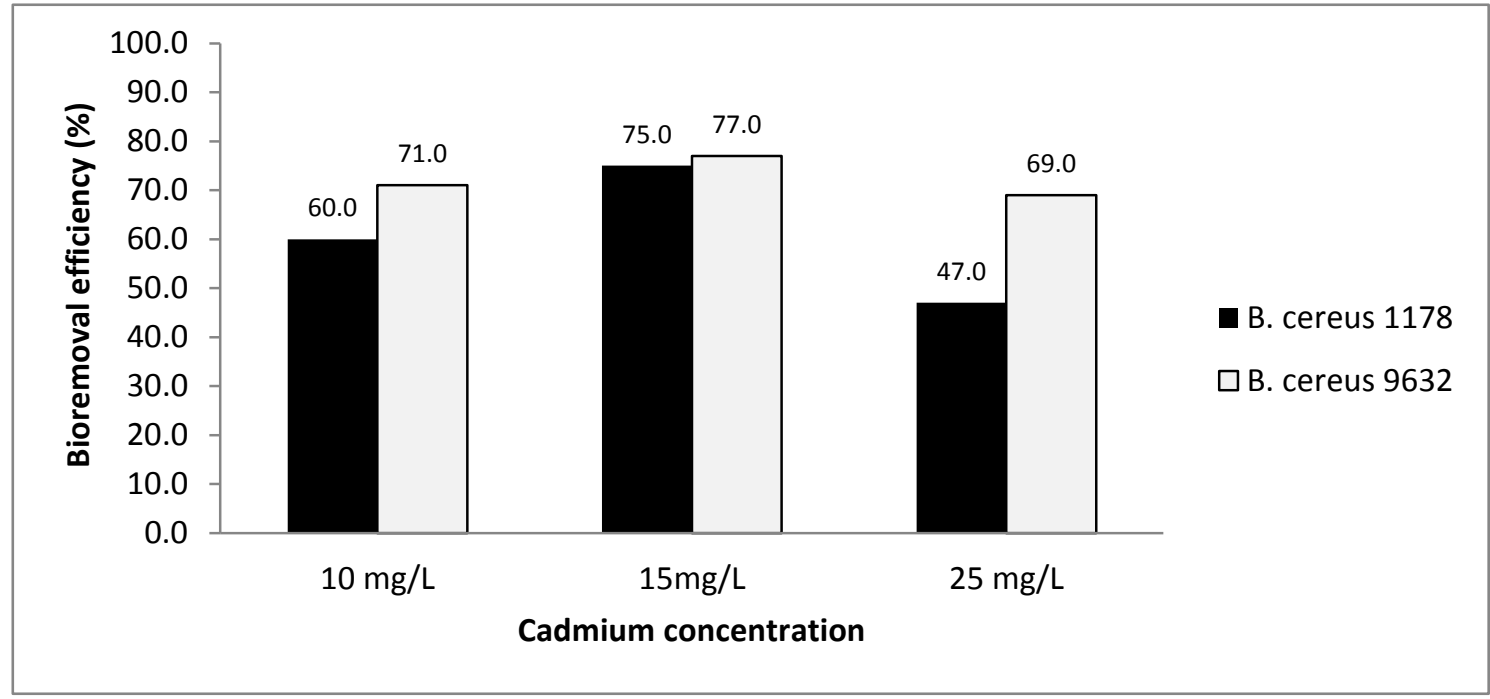

Figure 6. Bioremoval efficiency of cadmium by B. cereus ATCC 1178 and B. cereus ATCC 9632 